\title{
COMPARATIVE ANALYSIS OF THE CURRICULUM AT SCIENCE AND TECHNOLOGY (STEM) HIGH SCHOOLS IN POLAND AND THE UNITED STATES
}

\author{
Zygmunt Karol ŁUKASZCZYK ${ }^{1 *}$, Michalene Eva GREBSKI ${ }^{2}$ \\ ${ }^{1}$ Wydział Organizacji i Zarządzania/CKU, Politechnika Śląska, Poland; zygmunt.lukaszczyk@polsl.pl, \\ ORCID: 0000-0003-2370-1507 \\ ${ }^{2}$ Northampton Community College, Tannersville, PA 18466, USA; megrebski@northampton.edu, \\ ORCID: 0000-0002-3487-4473 \\ * Correspondence author
}

Introduction/Background: The knowledge-based economy in Poland and the United States (USA) requires highly trained engineering professionals to stay competitive and to secure economic development. In recent years, some initiatives have been undertaken to better prepare high school graduates for engineering and technology-related programs. One of these initiatives has been the creation of science, technology, engineering, and mathematics (STEM) high schools in Rybnik, Poland, and Hazleton, Pennsylvania (PA), USA.

Aim of the Paper: The comparative analysis of the curriculum was conducted by selecting two similar high schools, one in Hazleton, PA, USA, and one in Rybnik, Poland. The purpose of this research project was to identify the similarities and differences in the curricula at both high schools.

Materials and Methods: The authors of this article have firsthand experience with the curricula at both high schools. Both curricula are available in their respective catalogs. A comparative analysis of the curricula was done by identifying the best practices in both countries. Dual enrollment opportunities available to high school students in PA, is also discussed.

Results and Conclusions: This paper describes the different methods used for promoting interest in engineering and technology among high school students. These initiatives are necessary to provide a highly qualified workforce to meet the demands of the knowledge-based economy. This paper includes a comparative analysis of the STEM-oriented high school curricula in Poland and the USA.

Keywords: Engineering careers, technical education, promoting science, STEM schools.

\section{Introduction}

The knowledge-based economy in Poland and the United States (USA) requires highly trained engineering professionals to stay competitive and to secure economic development. Engineering programs have difficulty in recruiting qualified students despite the ever- 
increasing demand for Engineering graduates. Historically elementary and secondary schools were putting more emphasis on the arts and humanities at the expense of the sciences and mathematics. In recent years, some initiatives were undertaken to better prepare high school graduates for engineering and technology-related programs. Part of these initiatives was the creation of science, technology, engineering, and mathematics (STEM) high schools in Rybnik, Poland and Hazleton, Pennsylvania USA (Program of Studies). The purpose of both high schools is similar. Both high schools have the same educational objectives, that is, to better prepare high school graduates for engineering careers.

\section{Literature analysis}

\section{Literature analysis of the different methods for promoting STEM}

The literature lists different methods to promote interest in STEM careers. Han (2017) has studied the association between student interest and STEM careers and the public attitude towards science and technology. The research indicated that educators, such as teachers and the school principal need to pay attention to fostering individual level of interest in science and technology. Educators' attitudes towards science and technology plays a role in the development of STEM career expectations.

A study conducted by Zajac, et. al. (2017) indicted that graduates of disciplines, such as mathematics, technology and pharmaceutical have outshined others in the labor market. Graduates from biology and earth science programs did not perform as well.

Chirikov, et.al. (2020) evaluated the lack of qualified STEM instructor at the university level in Russia (Chirikov, I., Semenova, T., Maloshonok, N., Bettinger, E., and Kizilce, R.F., 2020, pp. 1-65). The largest global producers of STEM graduate China, India, Russia, and the United State are actively seeking policy alternatives to increase the cost-effectiveness of STEM education. Their research model relied on national online education platforms that were recently established in many countries, including China (XuetangX, WEMOOC, and CNMOOC), India (Swayam), and Russia (National Platform of Open Education/OpenEdu) to address challenges associated with the shortage of qualified instructors and growing demand for higher education.

Standardizing course content and random assignments were also studied. Qualitative and quantitative analysis were used to analyze the different conditions.

Erdogan and Stuessy (2015) did a literature analysis of sixty articles, reports or workshops. These sources had various focal points including, but not limited to demographics (race, gender, age) and types of schools. The methods of assessment included, but were not limited to openended questions, multiple choice tests, essays, reports, portfolios, presentations, and oral examinations. 
To improve STEM education and other facets of education in the United States, the Obama task force identified the different methods for promoting STEM (Education..., 2012).

Building partnerships among educators, businesses and community partners to support advances in STEM education was a priority for fortifying STEM education. Improving the coordination of STEM education initiatives between the Department of Education and National Science Foundation; and promoting over 100 industry partners in their efforts boost STEM learning. The STEM Master Teacher Corps was also an important component for promoting STEM education.

Li, et. al. (2020) used one hundred twenty-seven projects to research the trends in STEM education. Quantitative evaluation of STEM education focused on the expenditure (\% of GDP per capita) for STEM education, while the qualitative data focused on student and adult attitudes toward science and technology (Han, 2017). Statistical data also included categories, such as gender, immigration status, school characteristics, country characteristics, student ability and occupation of parents. Data was collected from fifty-five countries and sixty-six articles were referenced.

\section{Literature analysis of the effectiveness of different methods for promoting STEM}

Chirikov et.al. (2020) sited that the research at the university level indicated that to successfully master the university-level engineering courses, students must have a high schoollevel knowledge of physics, mathematics, and chemistry.

Erdogan and Stuessy (2015) focused their research on STEM school ecosystem as including advanced curriculum, expert teachers, policy makers, community leaders, role models, mentors and researchers as well as internships and immersion within STEM environments. In addition, the research also considered learning environments, curriculum, instructional strategies, advanced coursework, technology use, (teaching, learning, immersion, communication, partnering, mentoring, support, and assessment. The effectiveness of the different methods was analyzed in three types of schools which are categorized as selective/specialized, inclusive and STEM-focused career and technical education (CTE).

Li et. al. (2020) used one hundred twenty-seven projects to research the trends in STEM education and the effectiveness of the methods used in the projects, while Zajac, et.al. (2017) tracked graduates from STEM disciplines for twenty-one months after they entered the labor market. The effectiveness of STEM education has taken on significance in Poland since there is a $400 \%$ increase in secondary school students entering universities. This research provided conflicting data about the economic benefits of STEM disciplines versus Humanities and Social Science disciplines. 


\section{Purpose of the research/research hypothesis}

The comparative analysis of the curriculum was conducted by selecting two similar high schools, one in Hazleton, Pennsylvania (PA) USA and one in Rybnik, Poland. Both high schools have the same purpose of preparing students for an Engineering program at the university level. The purpose of this research project was to identify the similarities and differences in the curriculum at both high schools. The comparison of the curriculum was done from the perspective of identifying the best practices at both high schools for the purpose of the continuous quality improvement (CQI) process. The best practices need to be shared and duplicated. There will also be a need to learn from both the positive and negative experiences at the two schools.

There are two main research hypotheses, $\mathrm{H} 1$ and $\mathrm{H} 2$.

H1 - There are differences in promoting Science, Technology, Engineering and Mathematics (STEM) in Poland and the United States (USA).

$\mathrm{H} 2$ - There are best practices at both high schools, Liceum Ogolnosksztalcace Politechniki Slaskiej, and Hazleton Academy of Science which can be identified and shared for the purpose of continuous quality improvement.

\section{Methodology}

The research methodology consisted of the following:

- Literature analysis of the different methods for promoting STEM.

- Literature analysis of the effectiveness of the different methods for promoting STEM.

- Comparative analysis of the curriculum in the two STEM high schools in Rybnik, Poland and Hazleton, PA USA.

The curricula of the two high are available in their catalogs. The authors of this article have had first hand experience with the curriculum at both high schools, Hazleton, PA USA and Rybnik, Poland. A comparative analysis of the curricula was done by identifying the best practices in both countries. Dual enrollment opportunities available to high school students in Pennsylvania is also being investigated. Students in Poland do not have the dual enrollment opportunity.

\section{Comparison of the curricula of the STEM high schools in Poland and the USA}

A detailed educational plan for the STEM high school (Liceum Ogolnosksztalcace Politechniki Slaskiej) in Rybnik is shown in Table 1. 
Table 1.

Educational plan STEM high school Grades 9-12 (Liceum Ogolnosksztalcace Politechniki Slaskiej)

\begin{tabular}{|c|c|c|c|c|}
\hline \multirow[t]{3}{*}{ Mandatory Subjects } & \multicolumn{4}{|c|}{ Grade Level } \\
\hline & I (9) & II (10) & III (11) & IV (12) \\
\hline & \multicolumn{4}{|c|}{ Hours/Week } \\
\hline Polish Language & 4 & 4 & 4 & 4 \\
\hline $\begin{array}{l}\text { Foreign Language and Second } \\
\text { Foreign Language }\end{array}$ & 5 & 5 & 5 & 5 \\
\hline Philosophy or Art or Music & 1 & 0 & 0 & 0 \\
\hline History & 2 & 2 & 2 & 2 \\
\hline Social Sciences & 1 & 1 & 0 & 0 \\
\hline Entrepreneurship & 0 & 1 & 1 & 0 \\
\hline Geography & 1 & 2 & 1 & 0 \\
\hline Biology & 1 & 2 & 1 & 0 \\
\hline Chemistry & 1 & 2 & 1 & 0 \\
\hline Physics & 1 & 1 & 2 & 0 \\
\hline Mathematics & 3 & 4 & 3 & 4 \\
\hline $\begin{array}{l}\text { Information Science } \\
\text { Technology }\end{array}$ & 1 & 1 & 1 & 0 \\
\hline Physical Education & 3 & 3 & 3 & 3 \\
\hline Safety Education & 1 & 0 & 0 & 0 \\
\hline Etiquette & 1 & 1 & 1 & 1 \\
\hline $\begin{array}{l}\text { Total Hours for Mandatory } \\
\text { Subjects }\end{array}$ & 26 & 29 & 25 & 19 \\
\hline Hours/In-depth Subjects & 4 & 5 & 7 & 6 \\
\hline Total Hours for All Subjects & 30 & 34 & 32 & 25 \\
\hline
\end{tabular}

Students are enrolled in all required basis-level courses. They are also selecting two-to-three courses which are explored in-depth. The list of those in-depth courses is prepared by the school principal in consultation with the faculty as well as the students and parents. Faculty availability as well as the cost factor is also being considered. The typical courses offered in-depth are as follows:

- Polish Language.

- Social Sciences.

- History.

- Art History.

- Philosophy.

- Geography.

- Biology.

- Chemistry.

- Physics.

- Mathematics.

- Information Science Technology.

The in-depth courses are offered throughout the entire high school curriculum (Grades 9-12). 
As shown in Table 1, the students spend 25-35 hours/week in the classroom with an average of 30 hours/week.

The principal has the right to add four hours during the duration of the high school.

In addition to the subjects listed in Table 1, students are taking the following supplementary subjects:

- Religion/Ethics.

- Family Education.

- Minority Language (if the student belongs to an ethnic minority).

- Geography of the Student's Origin (if the student belongs to an ethnic minority).

- Sports Education/Professional Sports.

- Psychological and Pedagogical Assistance.

The time spent for those supplementary subjects may vary.

Career guidance for students needs to be at least ten hours during the four years of high school.

A detailed educational plan of the STEM high school (Hazleton Academy) is shown in Table 2 (Program...).

Table 2.

Educational plan STEM High School - Grades 9-12 (Hazleton Academy)

\begin{tabular}{|c|c|c|c|c|}
\hline \multirow[t]{3}{*}{ Mandatory Subjects } & \multicolumn{4}{|c|}{ Grade Level } \\
\hline & I (9) & II (10) & III (11) & IV (12) \\
\hline & \multicolumn{4}{|c|}{ Hours/Week for Mandated Subjects } \\
\hline English & 5 & 5 & 4 & 4 \\
\hline Foreign Language & 5 & 5 & 4 & 4 \\
\hline Fine Arts & 2 & 2 & 1 & 1 \\
\hline Social Sciences & 4 & 4 & 3 & 3 \\
\hline Biology & 3 & 3 & 0 & 0 \\
\hline Chemistry & 4 & 4 & 0 & 0 \\
\hline Physics & 0 & 0 & 3 & 3 \\
\hline Mathematics & 5 & 5 & 4 & 4 \\
\hline Communications & 0 & 0 & 0 & 3 \\
\hline $\begin{array}{l}\text { Information Science } \\
\text { Technology }\end{array}$ & 0 & 0 & 3 & 3 \\
\hline Physical Education & 2 & 2 & 2 & 2 \\
\hline \multicolumn{5}{|l|}{$\begin{array}{l}\text { Total Hours for Mandatory } \\
\text { Subjects }\end{array}$} \\
\hline \multicolumn{5}{|l|}{ Electives } \\
\hline Elective \#1 & 0 & 0 & 3 & 0 \\
\hline Elective \#2 & 0 & 0 & 0 & 3 \\
\hline Elective \#3 & 0 & 0 & 3 & 0 \\
\hline Elective \#4 & 0 & 0 & 0 & 3 \\
\hline Hours/Week for Electives & 0 & 0 & 6 & 6 \\
\hline Total Hours for All Subjects & 30 & 30 & 30 & 30 \\
\hline
\end{tabular}


In addition to the required courses, students need to take four elective courses. The accepted electives are as follows:

- Principles of Engineering.

- Computers and Robotics.

- Introduction to the Engineering Design Process.

- Computer Science and Programming.

- JAVA I.

- JAVA II.

- Digital Web Design.

- Managing Computer Information Systems.

- Organic Chemistry.

- Biochemistry.

- Anatomy and Physiology.

- Genetics.

- Astronomy.

Students have thirty hours/week in the classroom (six hours/day of instruction).

In addition, students are encouraged to participate in extracurricular activities after the school hours. Those activities are as follows:

- Engineering and Science Club.

- Sports' Activities.

- Marching Band.

- Concert Choir.

- Art Club.

- Other Clubs.

\section{Analysis of the similarities and differences of the STEM high school curricula in Poland and the United States}

Comparing the curricula of the STEM high schools in Poland and the United States (USA), the following similarities and differences have been identified (H1).

The similarities are as follows:

- The average time that students spend in the classroom is thirty hours/week.

- The mandatory subjects taken by the students are very similar. (History and Geography are offered under the Social Studies umbrella in the United States.)

- Both schools emphasize the foreign language requirement. 
The differences are as follows:

- The STEM high school (Hazleton Academy) in Hazleton, PA USA allows students to take more Engineering courses within the four electives. Students can select those four electives based on their interest and future academic plans.

- The STEM high school in Rybnik (Liceum Ogolnosksztalcace Politechniki Slaskiej) offers instruction in Entrepreneurship, Career Guidance as well as Etiquette.

- The STEM high school in Rybnik requires two-to-three courses to be taken in-depth.

\section{Dual enrollment opportunities}

Students enrolled at the Hazleton Academy (and other high schools) are eligible to take college courses while they are still in high school (Cassady, Keating, Young). This option is only available to students in the III and IV classes (Grades 11 and 12). The student must have an adequate grade-point average as determined by the university (H1).

Most engineering programs usually offer some introductory engineering courses which can be taken by STEM high school students. Those freshman college courses are taught by university faculty. They can be taken at a high school location during the school hours or at the college location after the school hours. STEM high school students enrolled in dual enrollment classes are required to pay a discounted college tuition based on an agreement between the university and the school district. Dual enrollment high school students are being considered college students as well. They receive a university identification card. The students can use the university library as well as the university computer system including a university email address. Their grades are also posted on a university transcript. After successfully passing the course(s), the course(s) appear on the university transcript as a college credit toward the engineering requirements. Most of those courses are transferrable between universities. If the student decides to change the university or decides to change the major/field of study, the course will be transferrable. Most students at a STEM high school take advantage of the dual enrollment opportunity (Cassady, Keating, Young).

The principal of the STEM high school cooperates with local college and university engineering programs on establishing the dual enrollment opportunities. Most university programs are very open and supportive of the dual enrollment concept. The university programs view dual enrollment program as a part of their recruitment and retention strategies.

From the university prospective, the tuition that the student is paying for taking college courses normally offset the expenses of offering the courses. The tuition is normally discounted by $50-75 \%$.

Periodically there are state and federal grants available to help STEM high school students pay the college tuition. The school district in conjunction with the Engineering program offering the dual enrollment course can submit a grant proposal for funding (STEM...; The Framework...). 
The students enrolled at the Hazleton Academy can take two college-level courses at Penn State Hazleton which are as follows:

- Introduction to Engineering Design, This course is offered as a freshman course in most engineering programs which are ABET accredited. The course has a project component and requires six contact hours per week for fifteen weeks. The six contact hours per week include two hours of lecture and four hours of hands-on projects. Introduction to Engineering Design also contains a graphics component including computer-aided design and drafting. Penn State Hazleton had a very positive experience in offering this course as a dual enrollment option.

- Speech Communication,

A speech communication course is normally a required course in any engineering curriculum. The course satisfies a general education requirement. A speech communication course requires three contact hours a week for fifteen weeks. The content of the course is focusing on the development of oral and written communication skills which are very important and helpful in preparing and delivering engineering presentations. Based on the experience at Penn State Hazleton, this course was considered the second choice for dual enrollment offerings (after the engineering design and graphics choice.

From the perspective of the Engineering program at Penn State Hazleton, this is an effective method to recruit well-prepared students into the Engineering program. Historically those students were hardworking and dedicated. Penn State Hazleton offers dual enrollment opportunities at four different school districts. A dual enrollment opportunity does not exist in the Polish educational system.

\section{Suggestions and recommendations based on best practices (H2)}

Based on the analysis of the similarities and differences between the two STEM high schools and best practices, the authors' suggestions and recommendations are as follows:

- Allow junior and senior high school students (Grades 11 and 12) in Poland to take selected college courses while they are in high school (this concept has been tested in the United States and it has produced positive results).

- Create at Liceum Ogolnosksztalcace Politechniki Slaskiej in Rybnik elective courses to allow the students to customize the curriculum according to their interests and future academic plans.

- Require students at the Hazleton Academy to take Entrepreneurship as a mandatory course.

- Incorporate instruction in Career Guidance and Etiquette into the Hazleton Academy curriculum. 


\section{References}

1. Cassady, L., Keating, K., and Young, V. Dual Enrollment: Lessons Learned on SchoolLevel Implementation. Virginia: EDJ Associates. https:/www.2.ed.gov/programs/skp/ finaldual.pdf, 01.07.2019.

2. Chirikov, I., Semenova, T., Maloshonok, N., Bettinger, E., and Kizilce, R.F. (2020). Online Education Platforms Scale College STEM Instruction with Equivalent Learning Outcomes at Lower Cost. Science Advances, Vol. 6, no. 15, pp. 1-65. advances.sciencemag.org> content>eaay5324, 05.14.2020.

3. Education: Knowledge and Skills for the Jobs of the Future. The White House: Barack Obama (2012). https://obamawhitehouse.archives.gov/issues/education/reform, 05.15.2020.

4. Erdogan, N., and Stuessy, C.L. (2015). Modeling Successful STEM High Schools in the United States: An Ecology Framework. International Journal of Education in Mathematics, Science and Technology, Vol. 3, No. 1, pp. 77-92. ISSN: 2147-611X. Files.eric.edu.gov/fulltext/EJ1059051.pdf, 05.14.2020.

5. Han, Seong Won (2017). What Motivates High-School Students to Pursue STEM Careers? The Influence of Public Attitudes toward Science and Technology in Comparative Perspective. Journal of Education and Work, Vol. 30, Iss. 6, pp. 632-652. ISSN: 1363-9080 (Print), 1469-9435, https://www.tandfonline.com/loi/cjew20, 05.14.2020. http://ijemst.com/pdfgoster.ph?file=depo/pdfs/pdf_3_2015_1.pdf, 05.14.2020.

6. https://www.niche.com/K12/search/best-schools-for-stem/s/pennsylvania, 01.07.2019.

7. Li, Yeping, Ke Wang, Yu Xian, Froyd, J.E., and Nite, S.B. (2020). Research and Trends in STEM Education: A Systematic Analysis of Publicly Funded Projects. International Journal of STEM Education 2020, Vol. 7, No. 17, https://stemeducationjournal. springeropen.com/articles/10.1186/s40594-020-00207-6, 05.15.2020.

8. Program of Studies. STEM School: Hazleton Area Academy of Sciences - School Year 2017-2018. https://www.hasdK12.org/Domain.1118, 01.07.2019.

9. Sanders, M. (2009). STEM, STEM Education, STEMmania. The Technology Teacher. International Technology Education Association. https://vtechworks.lib.vt.edu, 01.08.2019.

10. STEM: Pennsylvania Out-of-School-Time. Project Accelerate. https://www.pa.stem. ost.info, 01.07.2019.

11. Strauss, M. (2017). About a Third of Americans Would Tell High Schoolers Seeking Career Advice to Enter a STEM-related Field. Pew Research Center. www.pewsearch.org/facttank/2017/09/26, 01.08.2019. 
12. The Framework for Integrative Science, Technology, Engineering and Mathematics (STEM) Education Endorsement Guidelines (2014). Pennsylvania Department of Education. https://www.education.pa.gov/Documents/, 01.08.2019.

13. Zajac, T., Jasinski, M., and Bozykowski, M. (2018). Does It Pay to Be a STEM Graduate? Center for Studies of Higher Education (CSHE), Research and Occasional Paper Series: CSHE.13.17, University of California, Berkeley, pp. 1-9. Updated.final.ROPS,CSHE. 13.17.zajac.etal.PaytobeSTEMGrad.11.13/2017.docx， 05.14.2020. cshe.berkeley.edu/ sites/default/files/publications/updated/final.rops/cshe/cshe.13.17.zajac_et_al.paytobeste mgrad.11.13.2017.pdf, 05.14.2020. 